\title{
Role of lodine Deficiency in the Development of Menstrual Disorders in Young Females
}

DOI: $10.17691 / \mathrm{stm} 2016.8 .4 .14$

Received October 8, 2015

1.1. Gerasimova, MD, DSc, Professor, Department of Obstetrics and Gynecology, Rector';

M.S. Denisov, Clinical Resident';

A.V. Samoilova, MD, DSc, Professor, Head of the Department of Obstetrics and Gynecology2;

A.G. Gunin, MD, DSC, Professor, Department of Obstetrics and Gynecology2;

T.G. Denisova, MD, DSc, Professor, Department of Obstetrics and Gynecology2

'State Postgraduate Doctors' Training Institute, Ministry of Public Health of the Chuvash Republic,

3 Red Square, Cheboksary, 428032, Chuvash Republic, Russian Federation;

${ }^{2}$ Chuvash State University named after I.N. Ulyanov, 15 Moscow Avenue, Cheboksary, 428010,

Chuvash Republic, Russian Federation

The aim of the investigation was to study the effect of iodine level in young females on the development of menstrual disorders.

Materials and Methods. We determined iodine content in urine by a potentiometric method using ion-selective electrodes to analyze iodide ions. Due to the high amplitude vibrations of individual iodine concentrations in urine (ioduria) to estimate the severity of iodine deficiency, we used a mean iodine concentration in urine - a median.

Results. The content of urinary iodine excretion in young females with menstrual function disorders ranged widely from 18 to $109 \mu \mathrm{g} / \mathrm{L}$. The median of iodine excretion appeared to be lower than the existing standards, and was $74.8 \mu \mathrm{g} / \mathrm{L}$.

We revealed the positive direct relations between ioduria and impaired menstrual function ( $r=0.46)$. To assess the effectiveness of the program of iodine deficiency prevention of menstrual function in young girls 5-6 months after iodine administration, we re-evaluated their iodine level. The number of normal findings of urinary iodine excretions was found to have increased up to $70.6 \%$ cases, neither moderate nor severe iodine deficiencies being revealed. Moreover, most young females with menstrual disorders were found to have improved functioning of the reproductive system.

Key words: iodine deficiency disorders; menstrual disorders; iodine deficiency prevention.

Reproductive health of young people determines the nation health, and is of great importance for population reproduction. And having a direct impact on demographic processes it determines the future of society [1-3]. In current socio-economic environment reproductive health is characterized by an increasing prevalence of functional disturbances and chronic diseases.

Among the factors having a negative impact on reproductive health the higher priority belongs to stress and malnutrition. Etiopathogenetic role of nutrition under current conditions is considered as one of risk factors including iodine deficiency disorders. Malnutrition contributes to an increasing incidence of endocrine diseases, metabolic disorders, and causes the development of menstrual disorders. The monitoring of these conditions and iodine deficiency prevention are required in the population living in endemic areas [4-9]. lodine deficiency during pregnancy results in high-risk pregnancy undermining fetal central nervous system. There has been studied the negative effect of iodine deficiency in childhood [10-17].

The formation and development of female reproductive system is completed by the age of 16-19. lodine deficiency leads to thyroid dysfunction and significantly governs the physiology of reproductive system. We decided to study the iodine level in young females, when their reproductive system development is completed.

The aim of the investigation was to study the effect of iodine level in young females on the development of menstrual disorders.

Materials and Methods. We studied two groups of female students: group $1 \quad(n=34)$ young females had menstrual disorders (algodismenorrhea, dysfunctional uterine bleedings, amenorrhea); group $2(n=30)$ included young females with a physiological menstrual cycle.

The study complies with the declaration of Helsinki (adopted in June, 1964 (Helsinki, Finland) and revised in October, 2000 (Edinburg, Scotland)) and was approved by the Ethics Committee of Chuvash State University named after I.N. Ulyanov. All patients gave their written informed consent.

Blood samples were taken in the morning in numbered disposable containers. We determined iodine content in urine by a potentiometric method using ion-selective

For contacts: Tamara G. Denisova, e-mail: tomadenisova@rambler.ru 
electrodes to analyze iodide ions. Due to the high amplitude vibrations of individual iodine concentrations in urine (ioduria) to estimate the severity of iodine deficiency, we used a mean iodine concentration in urine - a median.

We determined an iodine level in urine on the base of a medical center "Otkrytie" (Cheboksary, Russia). To analyze iodine level we used mean urine iodine concentration scale recommended by the Ministry of Health of the Russian Federation in 1999 (norm $>100 \mu \mathrm{g} / \mathrm{L}$; slight deficiency: $50-100 \mu \mathrm{g} / \mathrm{L}$; moderate deficiency: $20-50 \mu \mathrm{g} / \mathrm{L}$; severe deficiency $<20 \mu \mathrm{g} / \mathrm{L}$ ).

The findings were statistically processed using Statistica (version 6.1) by parametric and non-parametric statistical methods (Student test, Mann-Whitney test).

Results and Discussion. Over $80 \%$ iodine is known to eliminate by kidneys, iodine concentration in urine fairly presents the iodine taken with food. To determine an iodine level in the groups of female students we analyzed urinary iodine excretion values.

Among females students with a physiological menstrual cycle, normal values $(100 \mu \mathrm{g} / \mathrm{L}$ and more) were found in $86.7 \%$, slight and moderated deficiency - in $13.3 \%$, mean ioduria value (median) was $118.5 \mu \mathrm{g} / \mathrm{L}$ (See the Table).

Urinary iodine excretion values in female students with menstrual disorders varied in a wide range from
18 to $109 \mu \mathrm{g} / \mathrm{L}$. loduria median was $74.8 \mu \mathrm{g} / \mathrm{L}$ and appeared to be lower than the norm. Normal values were found in $14.7 \%$, slight deficiency - in $61.8 \%$, moderate deficiency - in $17.3 \%$, severe deficiency in $5.8 \%$ females (See the Table). The patients with algodismenorrhea and dysfunctional uterine bleedings were revealed to have low and moderate iodine deficiency, while the cases with were found to have severe deficiency.

In order to reveal the dependence of menstrual dysfunction on iodine deficiency we carried out a correlation-regression analysis, and stated positive direct relations between ioduria and menstrual disorders $(r=0.46$ if $p<0.00001$ ).

To assess the efficiency of the program of iodine deficiency prevention of menstrual function we determine the iodine level in female students 5-6 months after iodine administration (See the Figure).

At the end of the period the number of normal urinary iodine excretion values in female students with menstrual disorders was found to increase being $70.6 \%$, no moderate and severe deficiencies being revealed. Moreover, the female students with menstrual disorders noticed the improvement in reproductive system functioning: pain syndrome manifestations decreased significantly during periods, and in some patients algomenorrhea disappeared, patients with dysfunctional

lodine level in female students according to ioduria values (\%)

\begin{tabular}{|c|c|c|c|c|c|}
\hline \multirow[b]{2}{*}{ Groups } & \multicolumn{5}{|c|}{ lodine status } \\
\hline & $\begin{array}{c}\text { Within } \\
\text { normal limits }\end{array}$ & $\begin{array}{c}\text { Slight } \\
\text { deficiency }\end{array}$ & $\begin{array}{l}\text { Moderate } \\
\text { deficiency }\end{array}$ & $\begin{array}{c}\text { Severe } \\
\text { deficiency }\end{array}$ & $p$ \\
\hline $\begin{array}{l}\text { Females with physiological } \\
\text { menstrual cycle }\end{array}$ & 86.7 & 8.9 & 4.4 & - & $\geqslant 0.02$ \\
\hline $\begin{array}{l}\text { Females with menstrual } \\
\text { disorders }\end{array}$ & 14.7 & 61.8 & 17.3 & 5.8 & $\geqslant 0.02$ \\
\hline
\end{tabular}

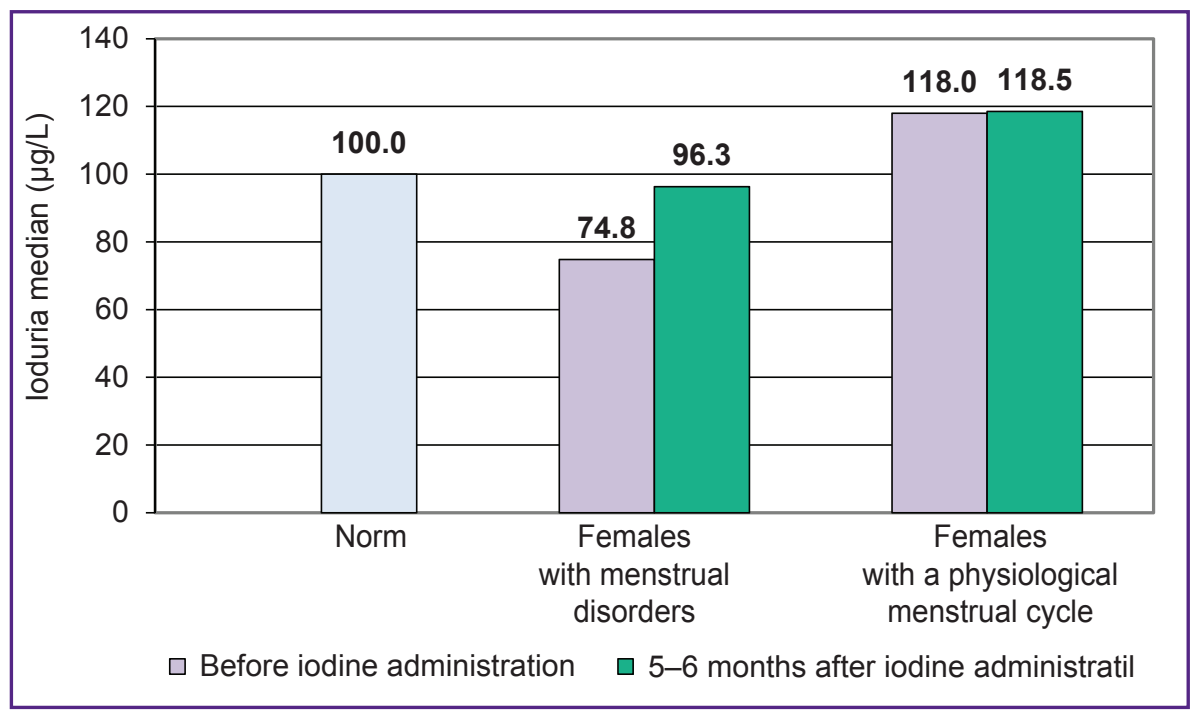

loduria median in young females of the study groups 
uterine bleedings mentioned the reduced number of bleeding events and decreased blood loss volume.

Thus, iodine deficiency prevention in females suffering from menstrual disorders has a positive effect on formation and physiological functioning of reproductive system.

Conclusion. One of the causes of menstrual dysfunction in young females can be iodine deficiency in diet. Control over iodine consumption and preventive measures for iodine recovery contribute to improved functioning of reproductive system.

Study Funding and Conflicts of Interest. The study was not funded by any sources, and the authors have no conflicts of interest related to the present study.

\section{References}

1. Yatskevich N.M. Ginekologicheskaya zabolevaemost' studentok: faktory riska, vozmozhnosti prognozirovaniya, ranney diagnostiki, profilaktiki i reabilitatsii. Avtoref. dis. ... kand. med. nauk [Gynecological morbidity of female students: risk factors, capabilities of prognosis, early diagnosis, prevention and rehabilitation. PhD Thesis]. Irkutsk; 2004.

2. Klinicheskaya endokrinologiya [Clinical endocrinology]. Pod red. Kholodovoy E.A. [Kholodova E.A. (editor)]. Moscow: Meditsinskoe informatsionnoe agentstvo; 2011; 736 p.

3. Serov V.N., Prilepskaya V.N., Ovsyannikova T.V. Ginekologicheskaya endokrinologiya [Gynecological endocrinology]. Moscow: MEDpressiform; 2008; 528 p.

4. World Health Organization. International Council for the Control of the lodine Deficiency Disorders. United Nations Children's Fund (WHO/ICCIDD/UNICEF). Assessment of the iodine deficiency disorders and monitoring their elimination. 3rd Edition. Geneva: World Health Organization; 2008.

5. Leung A.M., LaMar A., He X., Braverman L.E., Pearce E.N. lodine status and thyroid function of Boston-area vegetarians and vegans. J Clin Endocrinol Metab 2011; 96(8): E1303-E1307, https://doi.org/10.1210/jc.2011-0256.

6. Dedov I.I., Melnichenko G.A., Troshina E.A., et al. Defitsit yoda - ugroza zdorov'yu i razvitiyu detey Rossii. Puti resheniya problem. Natsional'nyy doklad [lodine deficiency a threat to the health and development of children in Russia. Ways of solving the problem. National report]. Moscow; 2006.

7. Ara G., Melse-Boon A., Roy S.K., Alam N., Ahmed S.,
Khatun U.H.F., Ahmed T. Sub-clinical iodine deficiency still prevalent in bangladeshi adolescent girls and pregnant women. Asian J Clin Nutr 2010; 2(1): 1-12, https://doi.org/10.3923/ ajcn.2010.1.12.

8. Assey V.D., Greiner T., Mzee R.K., Abuu H., Mgoba C., Kimboka S., Peterson S. lodine deficiency persists in the Zanzibar islands of Tanzania. Food Nutr Bull 2006; 27(4): 292299, https://doi.org/10.1177/156482650602700402.

9. Pearce E.N., Pino S., He X., Bazrafshan H.R., Lee S.L., Braverman L.E. Sources of dietary iodine: bread, cows' milk, and infant formula in the Boston area. J Clin Endocrinol Metab 2004; 89(7): 3421-3424, https://doi.org/10.1210/jc.2003-032002.

10. Morreale de Escobar G., Obregon M., Escobar del Rey F. Role of thyroid hormone during early brain development. Eur J Endocrinol 2004; 151(Suppl_3): U25-U37, https://doi. org/10.1530/eje.0.151u025.

11. Ausó E., Lavado-Autric R., Cuevas E., del Rey F.E., Morreale de Escobar G., Berbel P. A moderate and transient deficiency of maternal thyroid function at the beginning of fetal neocorticogenesis alters neuronal migration. Endocrinology 2004; 145(9): 4037-4047, https://doi.org/10.1210/en.2004-0274.

12. Koibuchi N., Chin W.W. Thyroid hormone action and brain development. Trends Endocrinol Metab 2000; 11(4): 123-128, https://doi.org/10.1016/s1043-2760(00)00238-1.

13. Chan S. Thyroid hormone and central nervous system development. J Endocrinol 2000; 165(1): 1-8, https://doi. org/10.1677/joe.0.1650001.

14. Delange F. Endemic cretinism. In: The thyroid. A fundamental and clinical text. Braverman L.E., Utiger R.D. (editors). Philadelphia: J.B. Lippincott; 1996; p. 756-767.

15. Glinoer D., Delange F. The Potential repercussions of maternal, fetal, and neonatal hypothyroxinemia on the progeny. Thyroid 2000; 10(10): 871-887, https://doi.org/10.1089/ thy.2000.10.871.

16. Santiago-Fernandez P., Torres-Barahona R., MuelaMartínez J.A., Rojo-Martínez G., García-Fuentes E., Garriga M.J., León A.G., Soriguer F. Intelligence quotient and iodine intake: a cross-sectional study in children. J Clin Endocrinol Metab 2004; 89(8): 3851-3857, https://doi. org/10.1210/jc.2003-031652.

17. Zimmermann M.B., Connolly K., Bozo M., Bridson J., Rohner F., Grimci L. lodine supplementation improves cognition in iodine-deficient schoolchildren in Albania: a randomized, controlled, double-blind study. Am J Clin Nutr 2006; 83(1): 108-114. 